\title{
3D Bioprinting in Medicine
}

\section{Fulden Ulucan-Karnak*}

Department of Biomedical Technologies, Graduate School of Natural and Applied Sciences, Ege University, Izmir, Turkey
Received: 28 December, 2020

Accepted: 11 January, 2021

Published: 12 January, 2021

*Corresponding author: Dr. Fulden Ulucan-Karnak, Department of Biomedical Technologies, Graduate School of Natural and Applied Sciences, Ege University, Izmir, Turkey, E-mail: ulucanfulden@gmail.com

Keywords: Bioprinting; 3D printing; Bioinks

https://www.peertechz.com

\section{Abstract}

3D bioprinting of tissues and organs is game changer and promising technology in medicine. It has also great potential to be substitution of animal models as artificial tissue or organ platforms and can be used for transplantation to the patient directly. Natural and synthetic polymers can be used as bioinks in order to develop tissue or organ models and they can be applied from benches to clinical application. In this review, it is aimed to summarize 3D printing technology in medicine and bioinks.

\section{Introduction}

The idea of bioprinting tissues, organs is very promising and extraordinary since 1980 's. First commercial bioprinter and 3D printers were developed in late of 1980's and development studies are still going on [1]. 3D printing technology is relied on Computer Aided Design (CAD) technology and digital images are returned to 3D structures with CAD tools. Then 3D structures at microscale and even nanoscale can be printed with 3D printers/ bioprinters with lower cost and higher flexibility and efficiency [2]. In last 20 years, this idea is evolved to printing of biological structures as bioprinting and several of bioprinting approaches have been carried out including stereolithography, extrusion, inkjet, laser and droplets based techniques for tissue and tissue substitutes and they were used from benches to clinical applications [3].

It is not possible to obtain fully functional and complex synthetic tissues or organs at all scales with a single bioprinting technique. It must be investigated and improved in terms of resolution, cell viability and bioinks. In literature, the most common used bioprinting techniques can be shown in Figure $1[4]$.

Inkjet-based bioprinting is using the conventional inkjet process of inkjet desktop printers and droplets of dilute solutions are dispensed with a non-contacting printer [5]. Drop demand inkjet technology is commonly used for bioprinting applications with thermal, piezoelectric, electrostatic and electrohydrodynamic printing technologies [6].

Laser-assisted bioprinting technique utilizes a laser as the energy source to place biomaterials onto a substrate. This technique has mainly three part as; a pulsed laser source, a metal film layer, and a receiving substrate. The resolution of this techniques is differentiated in between pico- to microscale [7].

The extrusion based bioprinting method is combination of a fluid-dispensing piston and an automated robotic system. A deposition system is released the bioink material and all process is under control of a computer. The extrusion based bioprinting has advantages as rapid fabrication, better structural integrity and CAD software adaptability [8].

Briefly, the main strategy for bioprinting of a tissue, various cells are collected from the patient and cultured in a cell culture system. Then it is mixed with a suitable biomaterial and the developed bioink is fed to the bioprinting system. After the fedding, 3D bioprinting process has started due to 3D pattern of the desired tissues $\mathrm{CAD} / \mathrm{CAM}$ image processing products. In Figure 2, 3D bioprinting steps of skin tissue were schematized [9].

Actually, 3D bioprinting process has several steps from starting to finalization. They can be classified as pre-printing, bioprinting and post-printing. In Table 1, this substeps are listed. Preprinting stage is extremely important in order to ensure that proper quality of the cells is obtained. Bioprinting stage is included bioink, bioprinter and bioprinting process which are effected by physicochemical, biological and other process based parameters. As a result of the bioprinting process, bioprinted materials are transferred to bioreactors in 


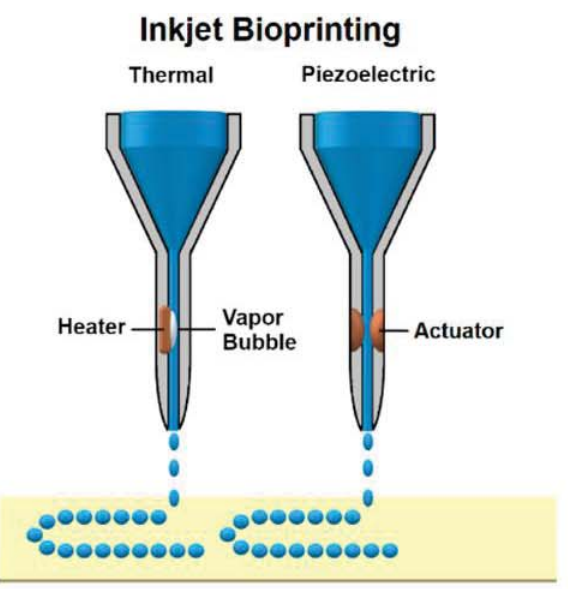

a

\section{Laser-assisted Bioprinting}

Laser Pulse

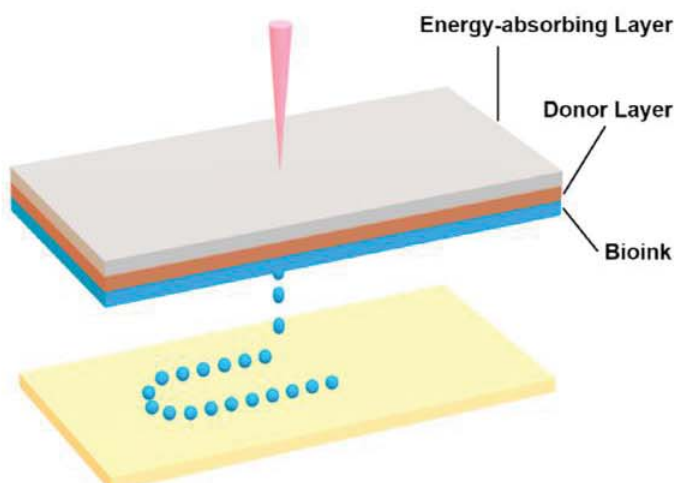

b

\section{Extrusion Bioprinting}

Pneumatic / Piston / Screw

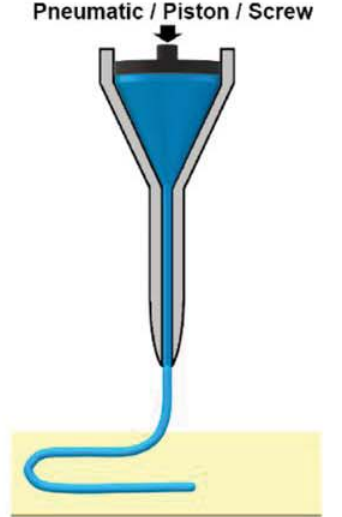

C

Figure 1: Common used bioprinting type: (a) Inkjet bioprinting, (b) Laser-assisted bioprinting, (c) Extrusion bioprinting [4].

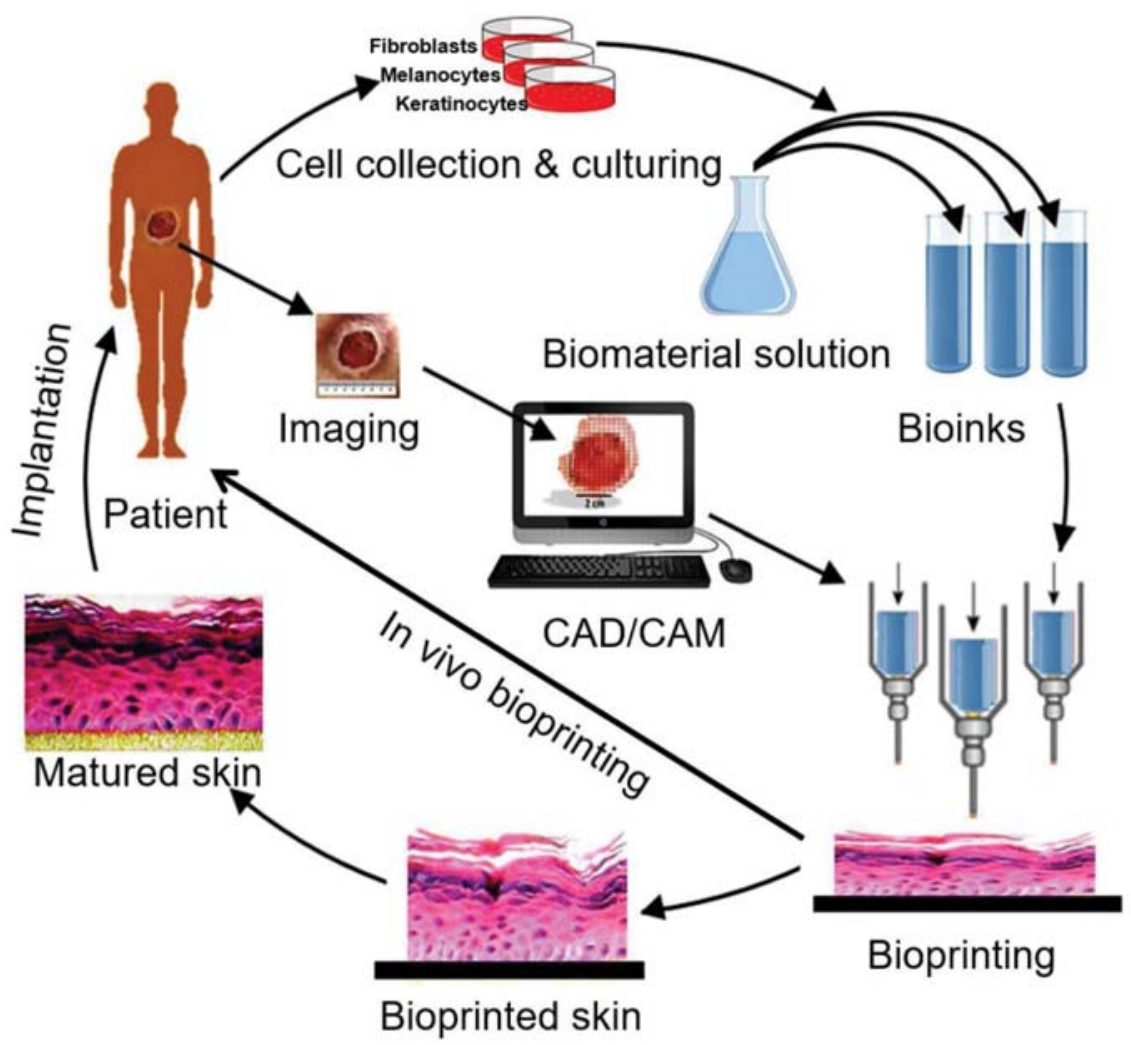

Figure 2: The 3D bioprinting process of skin tissue [9].

a part of post printing stage. In this stage, tissue maturation should be obtained by stimulation and developed tissue/organ can be monitored by biosensors with respect to functionality, rigidity and stability [10].

Recently, great efforts have been achieved in 3D cell culture development in order to fabricate of tissue constructs for application in research, tissue engineering, therapeutic, or drug screening. Bioprinting strategies will enable to construct a fully automated fabrication of matrix, cells, and bioactive layers instead of animal experiments [11]. 3D bio-printed tissues and organs are great alternatives to cell cultures and animal models as artificial platforms. This technology has already been used to fabrication and transplantation of important tissues such as bone, skin, heart tissue. Forming of 3D bio-printed model from 2D cell culture concludes complex steps such as cultivation in hydrogels, spheroids, membranes, 3D porous scaffolds, 3D fibrous scaffolds and so on [12].

3D bioprinting in medicial applications can include applications of dentistry, fabrication of tissue and organ models, fabrication of medical devices, fabrication of anatomical models 
and drug formulations [13]. 3D bioprinting is considered as a tool which is able to solve the problems for cancer patients by developing patient specific treatment via mimicking of in vitro models more closely real cancer conditions [14]. Medical 3D printing technology continues to develop rapidly in number of publications. Europe has the most publications followed by United State and China. Orthopedic applications are most published followed by otolaryngology, vascular and cardiac medicine. The leading applications in 3D printing of organs and tissues include vascular, skeletal, hepatic, and cardiac based, in the order of significance [15].

Nowadays, tissue specific functional 3D bioprinting is the new approach for transplantation applications in regenerative medicine. The overall purpose must be relied on fabrication of the tissues and organs with respect to desired shape and function and using them in vivo [16]

\section{Bioinks}

In 3D bioprinting technology, the material used to fabricate artificial tissue is called "bioink". It can be stabilized or crosslinked in order to obtain the final morphological and chemical structure of the design. Bioinks are produced from natural or synthetic biomaterials as alone, or their composites [17]. Bioink's requirements can be differentiate due to bioprinting techniques that will be used and substrate requirement can be taken shape according to process [18].

In bio-printing process, the major aim is defined as developing three dimensional complex and functional architectures. For this purpose, most suitable, stable and cellresponsive bioinks with chemical and physical properties are required. Researchers are commonly used naturally derived polymers or synthetic derived polymers such as gelatin methacryloyl (GelMA), Polyethylene Glycol Diacrylate (PEGDA) and Polyethylene Glycol Dimethacrylate (PEGDMA) $[16,19]$. The four types of bio-inks are listed as microcarriers, hydrogels, cell aggregates, and decellularized matrix components. Due to the chosen bioprinting technique, bio-inks should have certain properties such as viscoelasticity, flexibility, thermoresponsivity, shear-thinning and selfhealing [20].

Bio-inks which not include living cells are generally utilized for developing scaffold for cell culture. Typical scaffold materials are different forms of hydrogels [21]. Hydrogel based networks can be also performed as remodeled matrix and 3D environment for the normal development of functional tissues [22]. Hydrogels are generally biocompatible and they are commonly show non-Newtonian, shear thinning behavior, which is important for using in extrusion bioprinting [23]. In literature review, it can be seen that hydrogels were commonly used as bioinks for example bone [24], osteochondral grafts [25], cartilage [26] tissue engineering.

Bioinks may also contain cells in different forms and bioactive molecules or also biomaterials. It is understood that, bioinks is independent of biofabrication techniques and applications area [27]. There are several studies about bioink development and their cell/ tissue application in the literature.
It is very popular and demanding topic in biomedical and tissue engineering field. It is hard to mention all researches about 3D bioprinting but in Table 2 , most common bioink materials and some examples of their cell or tissue based applications were listed.

\begin{tabular}{|r|c|c|}
\hline Table 1: Steps in bioprinting [10]. \\
\hline Preprinting Stage & Bioprinting Stage & Post Printing Stage \\
\hline Tissue biopsy & Bioink & Nutrient/oxygen supply \\
\hline Stem cell differentiation/expansion & Bioprinter & Stimulation \\
\hline Imaging & Bioprinting process & \\
\hline Image processing & & \\
\hline Modelling & & \\
\hline Process modeling & & \\
\hline
\end{tabular}

Table 2. Most common bioinks and their applications.

\begin{tabular}{|c|c|c|}
\hline Bioinks & Cell/Tissue Type & Reference \\
\hline Alginate & Chondrocyte, cartilage & {$[28,29]$} \\
\hline Collagen & Hepatocytes & {$[30,31]$} \\
\hline Fibrin & Skeletal Muscle, Neural Tissues & {$[32,33]$} \\
\hline Hyaluronic acid & Fibroblasts, bone cells & {$[34,35]$} \\
\hline Poly(ethylene glycol)-PEG & Fibroblasts, cartilage & {$[36,37]$} \\
\hline Gelatin & Bone, cartilage & {$[38-41]$} \\
\hline
\end{tabular}

\section{Conclusion}

Three-dimensional (3D) printing of biological structures have great attention in last ten years and their application have started to utilize in regenerative medicine. This technology is in early progression step but it has huge possibility to implement in tissue engineering, drug delivery, cell/tissue and organ products, and other biomedical applications [42]. Despite of increasing articles, patent and researches of 3D bioprinting of living tissues or organs, it still faces significant challenges as unstable cellular behaviour and more complexities compared to non-biological printing process. In order to avoid these challanges, researchers need to work in multidisciplinary teams with engineers, biomedical scientists, basic scientist and medical doctors [43].

One of most important challenges of 3D bioprinting relies on in situ bioprinting as known as printing cells and biomaterials directly onto or in a patient [44]. However, the bioprinting technology is still being developed, it will be necessary to improve with ethical issues and related laws in order to use of 3D printers in industry, hospitals and academia. New regulations must be made before adopting developed prototypes into cilinical application $[45,46]$.

In the future, it is foreseen that researches will focus on enhancing 3D printing materials with respect to biocompatibility, mechanical properties, in situ bioprintability and sustainability of printed cells, tissues and organs via vascularization process [47]. Maintaning of cell viability, vascularization and cell migrations are the main limiting 
factors in generating of large sized, fully functional, tissues and organs. Especially vascularization is related to the nutrient diffusion process so it must be developed for realization of in vivo applications of 3D bioprinting [48]. Also novel bioinks were still developing in order to use as new scaffolds or unique cell, tissue applications. With these improvements, 3D bioprinting technology will be a revolutionary approaches in medicine.

\section{References}

1. Karzyński K, Kosowska K, Ambrożkiewicz F, Berman A, Cichoń J, et al. (2018) Use of 3D bioprinting in biomedical engineering for clinical application. Med Stud 34: 93-97. Link: http://bit.ly/3bvglcl

2. Zhu W, Ma X, Gou M, Mei D, Zhang $K$, et al. (2016) 3D printing of functional biomaterials for tissue engineering. Curr Opin Biotechnol 40: 103-112. Link: http://bit.ly/3shrGCP

3. Heinrich MA, Liu W, Jimenez A, Yang J, Akpek A, et al. (2019) 3D Bioprinting from Benches to Translational Applications. Small 15: 1-47.

4. Xie Z, Gao M, Lobo AO, Webster TJ (2020) 3D Bioprinting in Tissue Engineering for Medical Applications: The Classic and the Hybrid. Polymers (Basel) 12 1717. Link: http://bit.ly/2Xv0aUn

5. Rider $P$, Kačarević ŽP, Alkildani S, Retnasingh S, Barbeck M (2018) Bioprinting of tissue engineering scaffolds. J Tissue Eng 9: 204173141880209. Link: https://bit.ly/3bx4Hxy

6. Li X, Liu B, Pei B, Chen J, Zhou D, et al. (2020) Inkjet Bioprinting of Biomaterials Chem Rev 120: 10793-10833. Link: http://bit.ly/35yiPmC

7. Li J, Chen M, Fan X, Zhou H (2016) Recent advances in bioprinting techniques: approaches, applications and future prospects. J Transl Med 14: 271. Link: http://bit.ly/2XxdEPj

8. Ozbolat IT, Hospodiuk M (2016) Current advances and future perspectives in extrusion-based bioprinting. Biomaterials 76: 321-343. Link: https://bit.ly/3nvi7N6

9. Xu J, Zheng S, Hu X, Li L, Li W, et al. (2020) Advances in the Research of Bioinks Based on Natural Collagen, Polysaccharide and Their Derivatives for Skin 3D Bioprinting. Polymers 12: 1237. Link: http://bit.ly/2LFc5we

10. Datta P, Barui A, Wu Y, Ozbolat V, Moncal KK, et al. (2018) Essential steps in bioprinting: From pre- to post-bioprinting. Biotechnol Adv 36: 1481-1504. Link: http://bit.ly/3nCiMMw

11. Thayer P, Martinez H, Gatenholm E (2020) History and Trends of 3D Bioprinting Methods Mol Biol 2140: 3-18.

12. Charbe N, McCarron PA, Tambuwala MM (2017) Three-dimensional bioprinting: A new frontier in oncology research. World $\mathrm{J}$ Clin Oncol [Internet] 8 : 21. Link: http://bit.ly/2LFGFp

13. Liaw CY, Guvendiren M (2017) Current and emerging applications of 3D printing in medicine. Biofabrication 9.

14. Serrano DR, Terres MC, Lalatsa A (2018) Applications of 3D printing in cancer. J 3D Print Med 2: 115-127. Link: https://bit.ly/2LIqaZO

15. Chepelev L, Giannopoulos A, Tang A, Mitsouras D, Rybicki FJ (2017) Medical 3D printing: methods to standardize terminology and report trends. 3D Print Med 3: 4. Link: http://bit.ly/3qdlwli

16. Wang Z, Kapadia W, Li C, Lin F, Pereira RF, et al. (2020) Tissue-specific engineering: 3D bioprinting in regenerative medicine. J Control Release Link: https://bit.ly/2XunotP

17. Gungor-Ozkerim PS, Inci I, Zhang YS, Khademhosseini A, Dokmeci MR (2018) Bioinks for 3D bioprinting: an overview. Biomater Sci 6: 915-946. Link: http://rsc.li/2Xu2NFQ
18. Hospodiuk M, Dey M, Sosnoski D, Ozbolat IT (2017) The bioink: A comprehensive review on bioprintable materials. Biotechnol Adv 35: 217-239. Link: http://bit.ly/39sCvcA

19. Kim JS, Hong S, Hwang C (2016) Bio-ink Materials for 3D Bio-printing. J Int Soc Simul Surg 3: 49-59. Link: https://bit.ly/3shyikl

20. Donderwinkel I, van Hest JCM, Cameron NR (2017) Bio-inks for 3D bioprinting recent advances and future prospects. Polym Chem 8: 4451-4471. Link: http://rsc.li/3q9t08Y

21. Munaz A, Vadivelu RK, St. John J, Barton M, Kamble H, et al. (2016) Threedimensional printing of biological matters. J Sci Adv Mater Devices 1: 1-17. Link: http://bit.ly/3spowx9

22. Li J, Wu C, Chu PK, Gelinsky M (2020) 3D printing of hydrogels: Rational design strategies and emerging biomedical applications. Mater Sci Eng R Reports 140: 100543. Link: http://bit.ly/2XKFUyh

23. Ahangar $\mathrm{P}$, Cooke ME, Weber MH, Rosenzweig DH (2019) Current Biomedica Applications of 3D Printing and Additive Manufacturing. Appl Sci 9: 1713. Link: http://bit.ly/2LFcuPg

24. Neufurth M, Wang X, Schröder HC, Feng Q, Diehl-Seifert B, et al. (2014) Engineering a morphogenetically active hydrogel for bioprinting of bioartificial tissue derived from human osteoblast-like SaOS-2 cells. Biomaterials 35 8810-8819. Link: http://bit.ly/39opVev

25. Fedorovich NE, Schuurman W, Wijnberg HM, Prins HJ, van Weeren PR, et al. (2012) Biofabrication of Osteochondral Tissue Equivalents by Printing Topologically Defined, Cell-Laden Hydrogel Scaffolds. Tissue Eng Part C Methods 18: 33-44. Link: https://bit.ly/3sg63mo

26. Lee SJ, Rhie JW, Cho DW (2008) Development of Three-Dimensional Alginate Encapsulated Chondrocyte Hybrid Scaffold Using Microstereolithography. J Manuf Sci Eng 130. Link: https://bit.ly/39r8r0T

27. Groll J, Burdick JA, Cho DW, Derby B, Gelinsky M, et al. (2019) A definition of bioinks and their distinction from biomaterial inks. Biofabrication 11

28. Kesti M, Eberhardt C, Pagliccia G, Kenkel D, Grande D, et al. (2015) Bioprinting Complex Cartilaginous Structures with Clinically Compliant Biomaterials. Adv Funct Mater 25: 7406-7417. Link: https://bit.ly/2LgZQ9n

29. Markstedt K, Mantas A, Tournier I, Martínez Ávila H, Hägg D, et al. (2015) 3D Bioprinting Human Chondrocytes with Nanocellulose-Alginate Bioink for Cartilage Tissue Engineering Applications. Biomacromolecules 16: 14891496. Link: https://bit.ly/3nFPCMx

30. Mazzocchi A, Devarasetty M, Huntwork R, Soker S, Skardal A (2018) Optimization of collagen type I-hyaluronan hybrid bioink for 3D bioprinted liver microenvironments. Biofabrication 11: 015003. Link: https://bit.ly/38yiGS3

31. Lee $H$, Han W, Kim H, Ha DH, Jang J, et al. (2017) Development of Live Decellularized Extracellular Matrix Bioink for Three-Dimensional Cell PrintingBased Liver Tissue Engineering. Biomacromolecules 18: 1229-1237. Link: http://bit.ly/39oq5CD

32. Kim JH, Seol YJ, Ko IK, Kang HW, Lee YK, et al. (2018) 3D Bioprinted Human Skeletal Muscle Constructs for Muscle Function Restoration. Sci Rep 8: 12307. Link: https://go.nature.com/3qhqAoZ

33. Abelseth E, Abelseth L, De la Vega L, Beyer ST, Wadsworth SJ, et al. (2019) 3D Printing of Neural Tissues Derived from Human Induced Pluripotent Stem Cells Using a Fibrin-Based Bioink. ACS Biomater Sci Eng 5: 234-243. Link: https://bit.ly/35xtQEI

34. Ouyang L, Highley CB, Rodell CB, Sun W, Burdick JA (2016) 3D Printing of Shear-Thinning Hyaluronic Acid Hydrogels with Secondary Cross-Linking. ACS Biomater Sci Eng 2: 1743-1751. Link: https://bit.ly/3nDQuS1

35. Noh I, Kim N, Tran HN, Lee J, Lee C (2019) 3D printable hyaluronic acidbased hydrogel for its potential application as a bioink in tissue engineering Biomater Res 23: 3. Link: http://bit.ly/2MVSmJg 
36. Zheng Z, Wu J, Liu M, Wang H, Li C, et al. (2018) 3D Bioprinting of Self-Standing Silk-Based Bioink. Adv Healthc Mater 7: 1701026. Link: https://bit.ly/38Cligo

37. Cui X, Breitenkamp K, Finn MG, Lotz M, D'Lima DD (2012) Direct Human Cartilage Repair Using Three-Dimensional Bioprinting Technology. Tissue Eng Part A 18: 1304-1312. Link: https://bit.ly/3sg6IUU

38. Byambaa B, Annabi N, Yue K, Trujillo-de Santiago G, Alvarez MM, et al. (2017) Bioprinted Osteogenic and Vasculogenic Patterns for Engineering 3D Bone Tissue. Adv Healthc Mater 6: 1700015. Link: https://bit.ly/39qzfyq

39. de Ruijter M, Ribeiro A, Dokter I, Castilho M, Malda J (2019) Simultaneous Micropatterning of Fibrous Meshes and Bioinks for the Fabrication of Living Tissue Constructs. Adv Healthc Mater 8: 1800418. Link: https://bit.ly/3nAVdUG

40. Wenz A, Janke K, Hoch E, Tovar GEM, Borchers K, et al. (2016) Hydroxyapatitemodified gelatin bioinks for bone bioprinting. BioNanoMaterials 17. Link: https://bit.ly/2MVSRD8

41. Irmak G, Demirtaș TT, Gümüşderelio lu M (2019) Highly Methacrylated Gelatin Bioink for Bone Tissue Engineering. ACS Biomater Sci Eng 5: 831-845. Link: http://bit.ly/38B7tjH

42. Pahlevanzadeh F, Mokhtari H, Bakhsheshi-Rad HR, Emadi R, Kharaziha $\mathrm{M}$, et al. (2020) Recent Trends in Three-Dimensional Bioinks Based on
Alginate for Biomedical Applications. Materials (Basel) 13: 3980. Link: http://bit.ly/2MX8hac

43. Biazar E, Najafi SM, Heidari KS, Yazdankhah M, Rafiei A, et al. (2018) 3D bioprinting technology for body tissues and organs regeneration. J Med Eng Technol 42: 187-202. Link: https://bit.ly/3i7iPPi

44. Sears NA, Seshadri DR, Dhavalikar PS, Cosgriff-Hernandez E (2016) A Review of Three-Dimensional Printing in Tissue Engineering. Tissue Eng Part B Rev 22 298-310. Link: https://bit.ly/3bvhHDX

45. Tejo-Otero A, Buj-Corral I, Fenollosa-Artés F (2020) 3D Printing in Medicine for Preoperative Surgical Planning: A Review. Ann Biomed Eng 48: 536-555. Link: Link: https://bit.ly/39ljrx6

46. Kirillova A, Bushev S, Abubakirov A, Sukikh G (2020) Bioethical and legal issues in 3D bioprinting. Int J Bioprinting 6: 272. Link: http://bit.ly/35Agmla

47. Mao H, Yang L, Zhu H, Wu L, Ji P, et al. (2020) Recent advances and challenges in materials for 3D bioprinting. Prog Nat Sci Mater Int 30: 618-634. Link: http://bit.ly/2K7f14h

48. Hong N, Yang GH, Lee J, Kim G (2018) 3D bioprinting and its in vivo applications. J Biomed Mater Res Part B Appl Biomater 106: 444-459. Link: https://bit.ly/2LoayuA
Discover a bigger Impact and Visibility of your article publication with Peertechz Publications

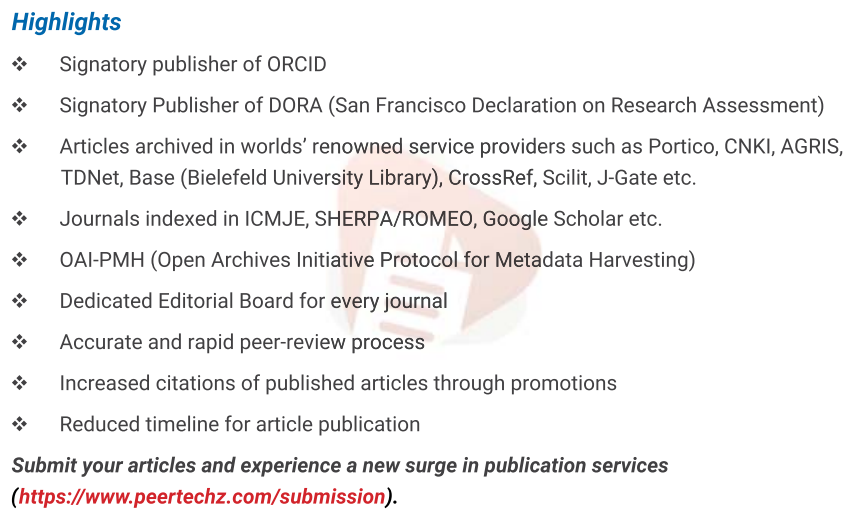

Peertechz journals wishes everlasting success in your every endeavours.

Copyright: (c) 2021 Ulucan-Karnak F. This is an open-access article distributed under the terms of the Creative Commons Attribution License, which permits unrestricted use, distribution, and reproduction in any medium, provided the original author and source are credited. 